\title{
First record of Chaetomium globosum causing leaf spot on Arachis hypogaea in China
}

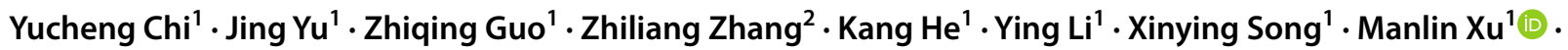 \\ Xia Zhang ${ }^{1}$
}

Received: 7 October 2021 / Accepted: 1 February 2022 / Published online: 2 March 2022

(c) The Author(s) under exclusive licence to Società Italiana di Patologia Vegetale (S.I.Pa.V.) 2022

In 2020, Arachis hypogaea grown in a greenhouse showed leaf lesions and a 20\% disease incidence rate. In 2021, A. hypogaea cultivated in the field showed the same symptoms and a 3\% disease incidence rate. Leaf lesions began as chlorotic lesions near the margins and progressed to necrotic lesions with chlorotic halos. The affected leaves ultimately withered and fell. Diseased leaves were surface disinfested in $75 \%$ ethanol for $20 \mathrm{~s}$, rinsed in sterile water, placed on PDA, and incubated at $25{ }^{\circ} \mathrm{C}$ in the darkness. Fungal colonies were initially white, then light brown, and finally turned olivaceous green to gray. The ascocarps were ovate, dark brown, with many appendages, which were brown and flexuous. The hyphae were septate, and ascospores (8.1$12.8 \times 6.8-8.84 \mu \mathrm{m}$ in size, $\mathrm{n}=50$ ) were broadly ovate, and slightly pointed at both ends.

Molecular identification was performed by sequencing the ITS (White et al. 1990) region and beta tubulin gene (Glass and Donaldson 1995) region (MZ474664 and MZ484689) of a representative isolate, ZHX8, which showed 100 and $99.75 \%$ similarity, respectively, to C. globosum (MH858130 and KT214742). Phylogenetic analysis of concatenated ITS and beta tubulin sequences confirmed

Manlin Xu

xumanlin@126.com

$\triangle$ Xia Zhang

zhangxia2259@126.com

1 Shandong Peanut Research Institute, Qingdao, Shandong, China

2 Institute of Characteristics Crops, Chongqing Academy of Agricultural Sciences, Chongqing, China the classification. A pathogenicity test was conducted using 10, 2-week-old seedlings by spraying leaves with an aqueous ascospore suspension $\left(10^{6}\right.$ spore $\left.\mathrm{mL}^{-1}\right)$, and control plants were sprayed with water. All the plants were incubated in the greenhouse at $25 \pm 2{ }^{\circ} \mathrm{C}$. After 10 days, the edges of leaves inoculated with ascospores were chlorotic, similar to the original symptoms observed in the field, whereas the control plants remained healthy. Koch's postulates were satisfied after reisolating $C$. globosum from spray-inoculated leaves. C. globosum has been reported on Punica granatum, Cannabis sativa and Brassica oleracea (Alam et al. 2021). To our knowledge, this is the first report of $A$. hypogaea leaf spot caused by $C$. globosum in China.

Supplementary Information The online version contains supplementary material available at https://doi.org/10.1007/s42161022-01070-w.

\section{References}

Alam MW, Malik A, Rehman A et al (2021) First Record of Chaetomium globosum Causing Leaf Spot of Pomegranate in Pakistan. Plant Dis 105(8):2241. https://doi.org/10.1094/PDIS-01-21-0200-PDN

Glass NL, Donaldson GC (1995) Development of primer sets designed for use with the PCR to amplify conserved genes from filamentous ascomycetes. Appl Environ Microbiol 61:1323-1330. https://doi.org/10.1002/bit.260460112

White TJ, Bruns T, Lee S, Taylor J (1990) Amplification and direct sequencing of fungal ribosomal RNA genes for phylogenetics. In: Innis MA, Gelfand DH, Sninsky JJ, White TJ (eds) PCR protocols: a guide to methods and applications. Academic Press, San Diego, pp 315-322

Publisher's Note Springer Nature remains neutral with regard to jurisdictional claims in published maps and institutional affiliations. 